\title{
JUURNAL.RU
}

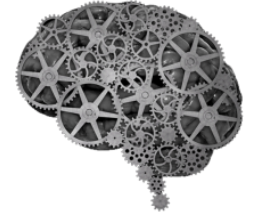

COMPANY GROUP "INTELLEKT"

Силантьева М. Ульяновский государственный педагогический университет имени И. Н. Ульянова

Ульяновск, Россия

doi: 10.18411/1j2016-5-4-11

\section{Сказкотерапия как метод воспитания младших школьников}

Аннотация: в статье анализируется применение сказкотерапии как метода воспитания младших школьников.

Ключевые слова: сказкотерапия, воспитание, младший школьник.

Abstract: the article analyzes using of fairytale therapy like a method of bringing up in a Primary School.

Keywords: fairytale therapy, child rearing, bringing up, Primary School.

Использование сказкотерапии, как метода воспитательного процесса младших школьников имеет большую актуальность в современной системе образования России, где наблюдаются изменения, представляющие собой этап расцвета новой школы, направленный следующий виток в образовании. Вследствие этого создаются и развиваются новые подходы в педагогической практики и теории учебно-воспитательного процесса. К этим подходам без сомнения относится и сказкотерапия.

Каждое старшее поколение во все времена передавало ценные сведения и нормы морали через занимательные истории, сказки, младшему. Это правильное решение - детский ум быстрее выхватывает яркие образы героев, являющихся оплотом нормы и морали, и укладывает в своём подсознании, как идеал, которому стоит подрожать.

Постепенно на основе сказок десятилетиями и годами складывалась 
сказкотерапия. Можно смело сказать, что тот метод, что мы имеем сейчас, складывался на опыте многих поколений. Сказка готовит нас к реалиям жизни через фантазию. Это одна из главных причин, почему наши предки уделяли этому там много времени.

Сказка через громкие метафоры и красивые слова рассказывает нам о жизни, судьбе и поступках, в короткое время учит, к чему могут привести те или иные поступки, дает шанс «примерить» на себя судьбу другого человека, его мысли и чувства. Эта индивидуальная возможность - «проиграть» различные ситуации без ущерба для собственного физиологического и психического здоровья - ставит сказку на одну ступень к эффективным способам воспитательной работы с детьми. Используя сокрытый в сказке опыт старшего поколения, ребенок познаёт свой собственный мир переживаний и чувств.

В современном мире сказки активно используются педагогами. Что, как не сказка, позволяет ребенку познать самого себя? Кто я? Каким бы я хотел видеть себя в будущем? А каким вижу себя в настоящем?

Сказкотерапия - это лечение сказками, это открытие знаний и опыта, что скрыт внутри нашей души. Сказку можно представить огромным пирогом, каждый кусочек которого пропитан своим индивидуальным смыслом. Во время чтения сказки, наше бессознательное уже “касается" каждого “кусочка со смыслом”, а затем ухватывает самый “вкусный” для себя, тот, который сможет дать ответ на нужный вопрос.

Сказкотерапия - это смысловой поиск, объяснения знаний об окружающей нас среде. В сказках существует целый список проблем человека и разные способы их решения. Слушая сказки в детстве, человек создаёт копилку жизненных ситуаций в своём бессознательном восприятии.

Сказкотерапия - это перенос сказочных символов в реальность. Рефлексия ребёнком после прочтения сказок поможет ему самостоятельно воссоздавать модели поведения и создать «копилку» для ценностей.

Когда ребёнок сталкивается с проблемами, он приходит к взрослым, но 
зачастую варианты, которые они ему предлагают, не являются решением. Но что же делать с накопившейся печалью, раздражением, гневом или радостью, которые уже переполняют ребенка? И здесь нам на помощь приходит сказкотерапия. Это те же самые сказки, но ориентированы они на определенную проблему. Это рассказ о ситуациях, в которые очень часто попадает ребенок, в нем описываются чувства, возникающие у ребенка, связанные с различными событиями жизни. Первое, ребенок понимает, что взрослых интересуют его проблемы, что родители на его стороне. Второе, он усваивает иной подход к жизни: «мы проживаем нашу жизнь так, как мы ее для себя строим». Третье, истории показывают, что выход есть всегда, нужно лишь его поискать.

В сказочных историях можно выделить следующие группы тем, которые они поднимают: трудности общения, чувство неполноценности, страхи и тревоги по самым различным поводам, проблемы, связанные со спецификой возраста. В результате сказкотерапии, ребенок чувствует поддержку взрослых, которая ему так необходима.

Как отмечает Шелби Б., ребенок, слушая, повторяя или выдумывая рассказы и сказки, дает волю своим чувствам, изливает дозу природной агрессивности.[4, с. 10-21] Некоторые рассказы способны вызвать у него страх, но это страх, замешанный на возбуждении и удовольствии. Неправильно полагать, что ребенок защищен от подобных эмоций. Напротив, желание эпизодически вспоминать мрачные и будоражащие воображение ситуации признак хорошего психологического здоровья.

В настоящее время большое количество внимания уделяют полоролевой идентификации. Как ребенку разобраться в различиях женского и мужского, если часто мамин стиль поведения — маскулинный, а папин — феминный? И в этом вопросе ребенку способна помочь сказка. Ведь в сказках представлены традиционные типы поведения: героев-мужчин всегда маскулинный, а женщин - феминный.

По ощущению мира сказка очень близка ребёнку, так как у него 
эмоционально-чувственное восприятие мира. В сказке есть лишь волшебные образы и четкая граница: здесь - Добро, а это - Зло, он персонаж - плохой, а этот - хороший. Это упорядочивает сложные чувства ребенка, а благополучный конец позволяет поверить в то, что в будущем и он сделает чтото хорошее.

Сказочные фантазии ребенка оказывают педагогическим усилиям действенную помощь; одновременно они делают возможным глубокое проникновение во внутреннюю жизнь фантазии, с учетом которой сознательное поведение становится более понятным и благодаря этому доступным для воздействия.

Безусловно, сказкотерапия - это новый виток в педагогических и авторских концепциях, но в тоже время он подкреплён опытом многих поколений. Поэтому изучение влияния сказкотерапии как метода воспитательного процесса на детей младшего школьного возраста, вне сомнения, эффективно. 


\section{Литература:}

1. Вачков И. Введение в сказкотерапию. - М.: «Гезезис». 2011 г.

2. Короткова Л.Д. Сказка - для светлого ума закваска. - М.: «Педагогическое общество России». 2001 г.

3. Ткач Р.М. Сказкотерапия детских проблем. - М.: «Речь». 2009 г.

4. Шелби Б. Открой своего ребенка с помощью тестов. - Тюмень: "Скорпион", 1995 г. 